\title{
HPLCによる簡便なミトタン血中濃度測定法の開発および適用
}

\author{
内山将伸 ${ }^{* 1}$, 原 周司 ${ }^{2}$, 緒方憲太郎 ${ }^{1}$, 今村 健 $^{1}$, 高松 泰 $^{3}$, 田村和夫 ${ }^{3}$, 二神幸次郎 ${ }^{1}$ \\ 福岡大学病院薬荗部 ${ }^{1}$, 福岡大学薬学部医療構造学 ${ }^{2}$, 福岡大学医学部腫瘍・血液・感染症内科学 ${ }^{3}$
}

\section{A Simple and Rapid HPLC Method for the Determination of Mitotane in Human Plasma and its Application to a Patient}

\author{
Masanobu Uchiyama*1, Shuuji Hara², Kentaro Ogata', Takeshi Imamura', \\ Yasushi Takamatsu ${ }^{3}$, Kazuo Tamura $^{3}$ and Koujiro Futagami ${ }^{1}$ \\ Department of Pharmacy, Fukuoka University Hospital ${ }^{1}$, \\ Faculty of Pharmaceutical Sciences, Fukuoka University ${ }^{2}$, \\ Division of Medical Oncology, Hematology and Infectious Disease, Fukuoka University ${ }^{3}$ \\ $\left[\begin{array}{l}\text { Received August 30, } 2011 \\ \text { Accepted December 11, } 2011\end{array}\right]$
}

Mitotane has been used for adrenal cancer and inoperable Cushing's syndrome. In a previous study, monitoring of the plasma mitotane level is important for assessments of efficacy and adverse drug reactions such as digestive symptoms. A simple and highly sensitive high-performance liquid chromatographic method was developed for the determination of mitotane in human plasma. Mitotane and 2,2-diphenylpropane as an internal standard were extracted from plasma with ethyl acetate. They were separated by a J'sphere ODS-H80 column with a mixture of methanol-acetonitrile-water (81:6:13, $\mathrm{v} / \mathrm{v} / \mathrm{v}$ ) as a mobile phase, and were then detected with a UV detector at $210 \mathrm{~nm}$. The within- and between-day variations for Mitotane were reliable. The method is very simple, rapid, sensitive and selective for mitotane, and may therefore be useful as a routine analysis for the therapeutic drug monitoring of mitotane.

Key words — mitotane, high performance liquid chromatography, adrenal cancer, plasma concentration

\section{緒 言}

ミトタン (1,1-dichloro-2-[o-chlorophenyl $]-2$ [p-chlorophenyl] ethane：DDD, Fig. 1）は副腎皮 質細胞を破壊する作用と種々のステロイド合成酵 素阻害作用を有することから，本邦では 1984 年 3 月から副腎がんおよび手術不能のクッシング症 候群の治療薬として使用されている。副腎がんは 極めて頻度が低い疾病であるが，5年生存率が 20 〜 35\%であり, 根治的手術が不可能な症例や再発 症例には DDD が薬物療法の中心を担っている. DDD の抗腫瘍効果は血中濃度に依存し, trough 值が 14〜 $20 \mu \mathrm{g} / \mathrm{mL}$ の範囲で抗腫瘍効果が期待で
きるとされ, 消化器症状, 神経 - 精神症状や中枢 神経中毒症状といった副作用は trough 值が $20 \mu \mathrm{g} /$ $\mathrm{mL}$ 以上で起こりやすいことが報告されている ${ }^{1 \sim 3)}$. 従って, DDD 療法を効果的に施行するには DDD の血中濃度モニタリングが必要である ${ }^{4)}$.また, DDD は毒性が強いため, 副作用を回避するため に low-dose $(2-3 \mathrm{~g} /$ day $)$ より開始し, $3 \sim 5$ 力月 後に目標值（trough 值 14-20 $\mu \mathrm{g} / \mathrm{mL} ） に$ 到達させ る方法が推奨されている ${ }^{5)}$.

現在, DDDの測定法としては Francia ら ${ }^{6)}$ が開 発した方法が繁用されている。この測定法は DDD およびその代謝物を同時測定することができる が，前処理として溶媒および固相抽出を必要とす

*福岡県福岡市城南区七隈七丁目45番1号 
(A)

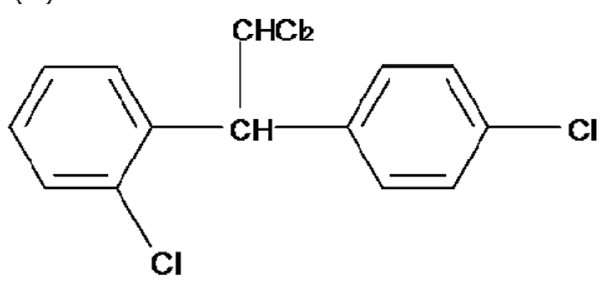

(B)

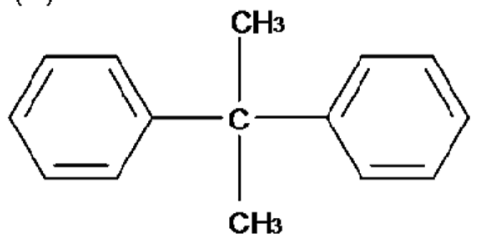

Fig. 1 Chemical structures of $\operatorname{DDD}(A)$, and $\operatorname{DPP}(B)$ as an internal standard.

るため煩雑である。また，代謝物の一つである 1,1-dichloro-2-[p-chlorophenyl]-2-[o-chlorophenyl] ethane（DDE）は 12 力月を越える長期的な予後 に関係しているという報告》もあるが，未だ明ら かにはされていない.

今回, 副腎がん患者に対して DDD を low-dose （1 g/day）から開始することになり，血中モニ夕 リングをする機会を得た，そこで，DDDの日常 分析に適した簡便な測定法を開発し, 患者の血中 DDD モニターを行った。

\section{方 法}

\section{1. 試薬}

DDD および 2,2-diphenylpropane（DPP, Fig. 1) は Sigma-Aldrich 社より購入した。メタノール, エタノール，アセトニトリル，酢酸エチルおよび 精製水は HPLC 用を用いた。その他の試薬は市 販特級品を使用した。

\section{2. 標準溶液および内部標準物質の調製}

DDD 標準溶液は DDD $15.0 \mathrm{mg}$ をエタノールに 溶解して $10 \mathrm{~mL}$ とした. 同様に内部標準物質 (IS) として DPP $13.0 \mathrm{mg}$ をエタノールに溶解して 10 $\mathrm{mL}$ とした。これらの溶液はそれぞれ $4^{\circ} \mathrm{C}$ で保存し 少なくとも2 カ月間は安定であった.

\section{3. 検量線用スタンダードの調製}

検量線用スタンダードは DDD 標準溶液（1.5 $\mathrm{mg} / \mathrm{mL}$ ）をエタノールで希釈し，DDD 濃度がそれ ぞれ $25.0,62.5,125,250,375,750 \mu \mathrm{g} / \mathrm{mL}$ とした. 本 DDD 溶液を健常人の血漿中濃度で $0.5,1.25,2.5$, 5.0, 7.5, $15.0 \mu \mathrm{g} / \mathrm{mL}$ となるよう調製した.

\section{4. 測定機器および測定条件}

HPLC 分析装置には日立 L-7120 ポンプおよび 日立 L-7405 紫外・可視検出器を用いた。分析力 ラムには J'sphere ODS-H80 column $(4 \mu \mathrm{m}, 4.6 \mathrm{~mm}$ $\times 150 \mathrm{~mm}, \mathrm{YMC}$ ）を用い，ガードカラムとして YMC-ODS（3 mm, $2.0 \times 10 \mathrm{~mm})$ を室温（15〜

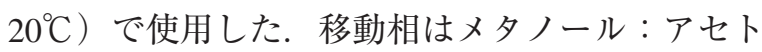
ニトリル: 水 $=81: 6: 13(\mathrm{v} / \mathrm{v} / \mathrm{v})$ を $1.0 \mathrm{~mL} / \mathrm{min}$ で送液して分析を行った. HPLC 注入量は $15 \mu \mathrm{L}$ で, $210 \mathrm{~nm}$ で検出した。 DDD 濃度は IS に対す るピーク面積比から求めた.

\section{5. 試料調製}

$5 \mathrm{~mL}$ のねじ口試験管に, 血漿試料 $500 \mu \mathrm{L}$ を分 取し, $10 \mu \mathrm{L}$ の IS 溶液, 約 $50 \mathrm{mg}$ の $\mathrm{NaCl}$ および $900 \mu \mathrm{L}$ の酢酸エチルを順次添加し, Vortex-mixer で約 5 分間摚找する。遠心分離 $(2000 \times \mathrm{g}, 10$ 分 $)$ 後, 酢酸エチル層を $1.5 \mathrm{~mL}$ の遠心用チューブに 分取し, $50^{\circ} \mathrm{C}$ で減圧乾固する. 残渣をエタノール $100 \mu \mathrm{L}$ に再溶解し， $15 \mu \mathrm{L}$ を HPLC に注入した.

健常人血漿は当研究室員からボランティアとし て提供を受けた。

\section{6. 精度および真度}

日内再現性は $0.5,2$ および $10 \mu \mathrm{g} / \mathrm{mL}$ になるよ うに調製した DDD の血漿試料について各濃度に つき 5 回繰り返し定量することによって評価し た。また，同様の濃度で 5 日間にわたり定量する ことで日間再現性を評価し, 真度は（定量值／理 論值）×100\%として評価した。

\section{7. 患者背景}

72 歳, 女性, 身長 $152 \mathrm{~cm}$, 体重 $44 \mathrm{~kg}$

約 30 年前に副腎がんに対して, 左副腎全摘術 を施行された. 左腎, 肝臓, 左肺横隔膜, 横行結 
腸，傍大動脈リンパ節転移および腹腔腫瘍に対し て，切除を繰り返していた。約 5 年前に転移性骨 腫瘍を認め，放射線治療が実施されていた。患者 はフェンタニルやアミトリプチリン，イミダプリ ル, 硝酸イソソルビド, モサプリド, ゾルピデム, ランソプラゾール, 酸化マグネシウム, センノサ イドを服用中であった。

\section{8. 患者血漿試料}

DDDを $1000 \mathrm{mg} / \mathrm{day}$ ( 1 〜 9 日目), $3000 \mathrm{mg} / \mathrm{day}$ (10〜25日)，4500 mg/day（26〜71 日目）にてそ れぞれ服用し，いずれも $3 ， 12 ， 28$ 日目にペパリ ン処理採血管にて採血を行った。採血時刻は $1000 \mathrm{mg} / \mathrm{day}$ 服用時は 2, 4 時間後, $3000 \mathrm{mg} / \mathrm{day}$ では 2, 4, 6 時間後, $4500 \mathrm{mg} /$ day では 2, 4, 6 時間後にそれぞれ採血した後, 速やかに遠心分離 し, 得られた血漿を測定まで $-20^{\circ} \mathrm{C} て ゙$ 凍結保存し た．対象患者へは担当医師よりヘルシンキ宣言に 基づき十分に説明し書面にて同意を得て，血中濃 度測定を行った。

本研究は福岡大学病院臨床研究審査委員会の審
査および承認を得ている.（承認番号：第11-1116 号)

\section{結果}

\section{1. クロマトグラム}

DDD および IS を添加した健常人血漿（A）お よび DDD 服用患者（B）より得られたクロマト グラムを Fig. 2 に示す. DDDのピークが約 6 分, IS のピークが約 7 分に検出され, 患者血漿より 得られたクロマトグラムにおいて，内因性物質お よびほかの治療薬における妨害ピークは検出され なかった。

\section{2. 直線性}

検量線は DDD の添加血漿濃度に対する, IS の ピーク面積と DDDのピーク面積比より求めた. 検量線は DDD 濃度として $0.5 \sim 15 \mu \mathrm{g} / \mathrm{mL}$ の濃度 範囲に押いて良好な直線性を有し, 回帰直線は, $y=3.2861 x+0.0727$ であり, 相関係数 $(r)$ は 0.999 であった.
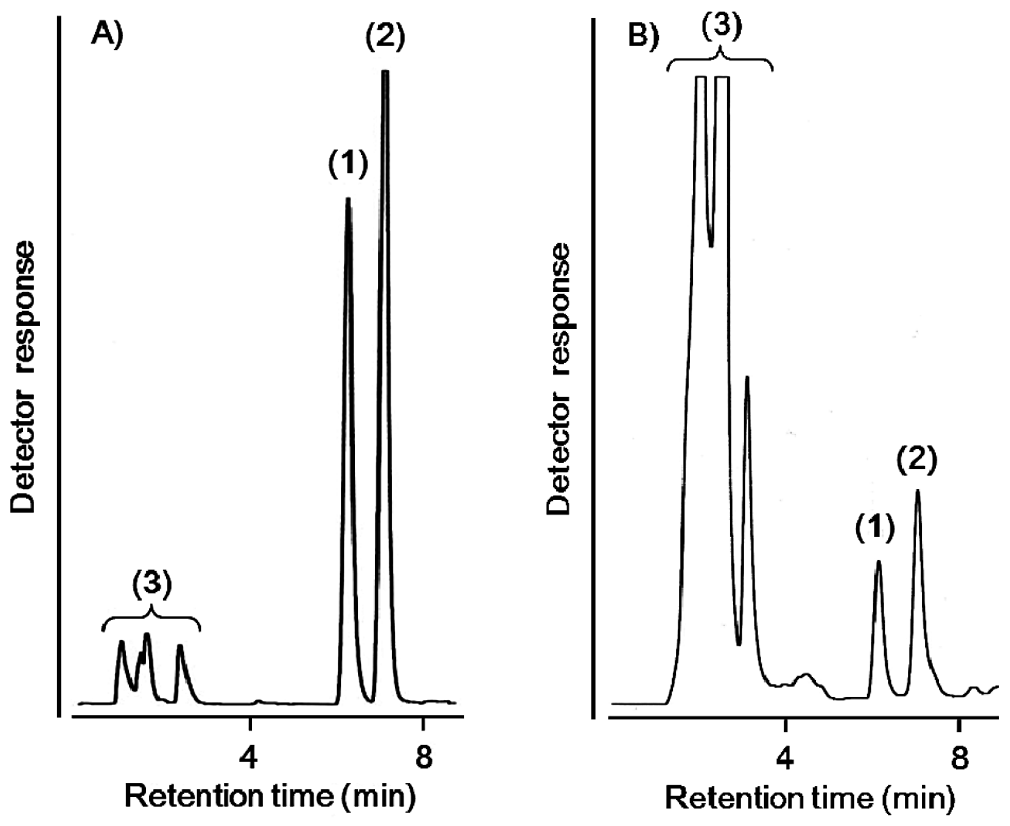

Fig. 2 Chromatograms obtained from human blank plasma spiked with mixture of DDD $(5 \mu \mathrm{g} / \mathrm{mL})$ and IS $(13 \mu \mathrm{g} / \mathrm{mL})$ (A) and from a patient plasma after the treatment with mitotane $(3.05 \mu \mathrm{g} / \mathrm{mL})$ (B). Peaks: 1, DDD; 2, IS; 3, unknown. 
Table 1 The within-and between-day precisions of the HPLC method for determining mitotane in plasma sample.

\begin{tabular}{crcc}
\hline \hline \multirow{2}{*}{$\begin{array}{c}\text { DDD added } \\
\text { concentration }(\mu \mathrm{g} / \mathrm{mL})\end{array}$} & $\begin{array}{c}\text { within-day } \\
(\mathrm{n}=5 \text {, each })\end{array}$ & $\begin{array}{c}\text { between-day } \\
(\mathrm{n}=5 \text {, each })\end{array}$ \\
\cline { 3 - 4 } & $\operatorname{RSD}^{1)}(\%)$ & $\operatorname{RSD}^{1)}(\%)$ \\
\hline \multirow{3}{*}{ Mitotane } & $0.5 \mu \mathrm{g} / \mathrm{mL}$ & 5.5 & 5.7 \\
& $2 \mu \mathrm{g} / \mathrm{mL}$ & 3.5 & 4.2 \\
\hline
\end{tabular}

1) RSD : relative standard deviation

Table 2 Concentrations of a plasma sample obtained from an adrenal cancer patient subject.

\begin{tabular}{cccc}
\hline \hline Day & Daily Dose & Time & $\begin{array}{c}\text { Concentration } \\
(\mu \mathrm{g} / \mathrm{mL})\end{array}$ \\
\hline 3 & $1000 \mathrm{mg}$ & $2 \mathrm{~h}$ & 1.60 \\
3 & $1000 \mathrm{mg}$ & $4 \mathrm{~h}$ & 3.05 \\
\hline 12 & $3000 \mathrm{mg}$ & $2 \mathrm{~h}$ & 8.86 \\
12 & $3000 \mathrm{mg}$ & $4 \mathrm{~h}$ & 5.48 \\
12 & $3000 \mathrm{mg}$ & $6 \mathrm{~h}$ & 4.98 \\
\hline 28 & $4500 \mathrm{mg}$ & $2 \mathrm{~h}$ & 9.48 \\
28 & $4500 \mathrm{mg}$ & $4 \mathrm{~h}$ & 8.59 \\
28 & $4500 \mathrm{mg}$ & $6 \mathrm{~h}$ & 7.31 \\
\hline
\end{tabular}

\section{3. 精度および真度}

日内および日間再現性について評価した結果を Table 1 に示す。精度は変動係数（CV）として 評価し, 日内再現性は $1.8 \sim 5.5 \%$, 日間再現性は 2.5 〜 $5.7 \%$ であった。真度は（定量值／理論值） $\times$ $100 \%$ として評価し，日内再現性は99.9〜 104.7\%，日間再現性は 99.2〜107.0\%であった.

\section{4. 定量下限値}

DDD の定量下限值は $0.31 \mu \mathrm{g} / \mathrm{mL} （ \mathrm{~S} / \mathrm{N}=3 ）$ で あり，この濃度における日内再現性および日間再 現性における CV は $9.25 \%$ 以下であり，真度は 105.7 -108.0\%であった.

\section{5. 患者血漿中濃度}

$1 \mathrm{~g} /$ 日は 3 日目, $3 \mathrm{~g} /$ 日は 12 日目，4.5 g/日は 28 日目での患者DDD 血漿中濃度を測定した。そ の結果を Table 2 に示す.

\section{考察}

DDD は脂溶性が非常に高く, 患者個々の血中 濃度に大きなバラッキがみられる薬物である。ま た，抗腫瘍効果および副作用発現は濃度依存的で あるため，血中濃度を測定し，投与量を決定する ことが重要となる。

今回開発した測定法は酢酸エチルによる抽出の みで患者血漿中の DDD を簡便に測定することが 可能であった。 また，移動層をメタノール：アセ トニトリル：水 $=81 ： 6: 13(\mathrm{v} / \mathrm{v} / \mathrm{v})$ にすること で約 7 分と短時間の測定が可能となった.ささらに, 日内変動㧍よび日間変動も小さく, 各医療施設に おいても実施可能であると考えられる。

患者は DDD 開始後, 血漿中濃度および副作用 症状を観察しながら, 徐々に増量を行っていった。 しかし，治療域に到達する前の 71 日目に死亡退 院された。

現在，切除不能な副腎がんにおける治療では DDD と抗がん剂 (シスプラチン, ドキソルビシン， エトポシド等）との併用療法で高い有効性が示さ れている ${ }^{8 \sim 9)}$. また，副腎がんの high stage 症例 において DDD 単独で血中濃度を 14〜20 $\mu \mathrm{g} / \mathrm{mL}$ にコントロールした場合に長期生存 $(5$ 年生存率 : 67\%）が得られることも報告されている ${ }^{10)}$.

最近, DDD と電離放射線の併用により cellcycle に働き， G2/M 期で停止させることが報告さ れた ${ }^{11}$ 。このことは, DDDの適用拡大の可能性 を示唆する.

Francia ら $^{6}$ の方法では 2 段階の固相抽出といっ た煩雑な前処理を必要としていたが，本法は酢酸 エチルによる 1 回のみの抽出で非常に簡便で迅速 に血漿中 DDD 濃度の測定を可能とし, 日常分析 法として極めて有用であると考えられる.さらに， 代謝物の一つである DDE は長期的な予後への関 与が示唆されているものの, 未だ明らかにされて いない. また, 副作用を回避し $3 \sim 5$ カ月後に目 標值に到達させるために DDD の血中濃度モニタ リングは重要であり, 本法の臨床での有用性は高 いものと考えられる. 


\section{引用文献}

1) Haak HR, Hermans J, Velde CJ, Lentjes EG, Goslings BM, Fleuren GJ, Krans HM, Optimal treatment of adrenocortical carcinoma with mitotane: results in a consecutive series of 96 patients, $\mathrm{Br} J$ Cancer, 1994, 69, 947-951.

2) Slooten H, Moolenaar AJ, Seters AP, Smeenk D, The treatment of adrenocortical carcinoma with o, p-DDD: prognostic implications of serum level monitoring, Eur J Clin Oncol, 1984, 20, 47-53.

3) Baudin E, Pellegriti G, Bonnay M, Penfornis A, Laplanche A, Vassal G, Schlumberger M, Impact of monitoring plasma 1,1-dichlorodiphenildichloroethane (o, p'DDD) levels on the treatment of patients with adrenocortical carcinoma, Cancer, 2001, 92, 1385-1392.

4) Wängberg B, Khorram-Manesh A, Jansson S, Nilsson B, Nilsson O, Jakobsson CE, Lindstedt S, Odén A, Ahlman H, The long-term survival in adrenocortical carcinoma with active surgical management and use of monitored mitotane, Endocr Relat Cancer, 2010, 17, 265-272.

5) Terzolo M, Pia A, Berruti A, Osella G, Alì A, Carbone V, Testa E, Dogliotti L, Angeli A, Low-dose monitored mitotane treatment achieves the therapeutic range with manageable side effects in patients with adrenocortical cancer, J Clin Endocrinol Metab, 2000, 85, 2234-2238.

6) Francia SD, Pirro E, Zappia F, Martino FD, Sprio AE, Daffara F, Terzolo M, Berruti A, Carlo FD, Ghezzo F, A new simple HPLC method for measur- ing mitotane and its two principal metabolites tests in animals and mitotane-treated patients, J Chromatogr B Analyt Technol Biomed Life Sci, 2006, 837, 69-75.

7) Kasperlik-Zaluska AA, Cichocki A, Clinical role of determination of plasma mitotane and its metabolites levels in patients with adrenal cancer: results of a long-term follow-up, J Exp Ther Oncol, 2005, 5, $125-132$.

8) Bonacci R, Gigliotti A, Baudin E, Wion-Barbot N, Emy P, Bonnay M, Cailleux AF, Nakib I, Schlumberger M, Comète R, Cytotoxic therapy with etoposide and cisplatin in advanced adrenocortical carcinoma, Br J Cancer, 1998, 78, 546-549.

9) Terzolo M, Pia A, Angeli A, Dogliotti L, Mitotane associated with etoposide, doxorubicin, and cisplatin in the treatment of advanced adrenocortical carcinoma, Cancer, 1998, 83, 2194-2200.

10) Wängberg B, Khorram-Manesh A, Jansson S, Nilsson B, Nilsson O, Jakobsson CE, Lindstedt S, Odén A, Ahlman H, The long-term survival in adrenocortical carcinoma with active surgical management and use of monitored mitotane, Endocr Relat Cancer, 2010, 17, 265-272.

11) Cerquetti L, Sampaoli C, Amendola D, Bucci B, Misiti S, Raza G, Paula UD, Marchese R, Brunetti E, Toscano V, Stigliano A, Mitotane sensitizes adrenocortical cancer cells to ionizing radiations by involvement of the cyclin B1/CDK complex in G2 arrest and mismatch repair enzymes modulation, Int J Oncol, 2010, 37, 493-501. 